\title{
Pengaruh Minuman Keras Terhadap Kesehatan Mental Remaja
}

\author{
Zulfikar Eka Putra \\ IIK Strada Indonesia \\ zulfiep87@gmail.com
}

\begin{abstract}
Abstrak
Masa remaja merupakan masa dimana seseorang mengalami perkembangan serta peralihan dari masa anak-anak ke masa dewasa yang mencakup perkembangan fisik, intelektual, emosi, dan sosial. Pada masa remaja ini seseorang cenderung akan memiliki rasa keingin tahuan yang tinggi terhadap sesuatu di sekitarnya. Rasa ingin tahu yang besar inilah yang biasa membuat remaja ingin mencoba sesuatu hal baru, contohnya yaitu minuman keras. Kebiasaan minum minuman keras bagi para remaja bermula karena kurangnya informasi dan kesalahpahaman informasi, termakan iklan atau terbujuk rayuan teman. Banyak yang beranggapan bahwa meminum minuman keras dapat menghilangkan stress. Namun hal ini sangat tidak dibenarkan. Bahkan sebenarnya minuman keras itu tidak baik bagi kesehatan mental, karena dapat menyebabkan gangguan dalam fungsi berpikir, merasakan, dan berperilaku.
\end{abstract}

\section{Latar Belakang}

Modernisasi saat ini yang menjadi tanda awal dari kemajuan zaman telah memberikan beberapa pengaruh dan dampak bagi manusia di zaman sekarang. Modernisasi ini membawa dampak dalam berbagai bidang dan juga nilai kehidupan. Adanya modernisasi menyebabkan seluruh elemen di dalam masyarakat mengalami kemajuan dan perubahan. Modernisasi ini dapat di artikan sebagai perubahanperubahan di dalam masyarakat mengenai perubahan norma sosial, nilai sosial, susunan lembaga yang ada di masyarakat, pola perilaku sosial, dan segala aspek di dalam kehidupan sosial.

Modernisasi juga dapat berarti proses perubahan dari cara-cara tradisional ke cara-cara baru yang lebih maju, di mana dimaksudkan untuk meningkatkan kesejahteraan masyarakat. Secara sederhana, dapat dikatakan modernisasi ialah proses menuju masa kini atau proses menuju masyarakat yang modern.
Faktor utama penyebab modernisasi adalah berkembang pesatnya ilmu pengetahuan dan teknologi dalam masyarakat. Faktor sosial ekonomi yang ada di dalam masyarakat merupakan pemicu bagi individu untuk memunculkan perilaku dan pengalaman yang tidak sehat diantaranya adalah ketidak stabilan dalam rumah tangga, kekerasan anak, orang tua perokok, orang tua peminum, akses kesehatan yang sulit, polusi lingkungan, perokok berat, peminum berat, penyalahgunaan minuman keras dan narkoba oleh remaja.

Salah satu dampak dari modernisasi yang telah terlihat jelas di sekitar masyarakat adalah penyalahgunaan minuman keras pada kalangan remaja. Bila keadaan ini dibiarkan maka bencana yang akan terjadi, remaja yang telah keracunan alkohol atau minuman keras ini adalah remaja yang tidak efektif bagi kehidupan sosialnya.

Alkohol atau minuman keras ini termasuk dalam golongan zat adiktif yang dapat menimbulkan adiksi dan ketergantungan. Minuman keras ini juga adalah minuman 
yang mengandung zat etanol. Etanol sendiri adalah zat atau bahan yang bila dikonsumsi akan menurunkan tingkat kesadaran bagi konsumennya (mabuk).

\section{Kasus/ masalah}

Di daerah Tuban jawa timur, meminum minuman keras keras sudah menjadi kebiasaan bagi banyak orang. Bahkan banyak juga dari kalangan remaja yang menyukai minuman keras. Para remaja ini biasa meminum minuman keras pada saat malam hari atau pagi hari sebelum beraktivitas. Dan ketika para remaja ini meminum minuman keras mereka selalu melakukannya beramai ramai, sehingga terkadang menyebabkan kegaduhan.

\section{Tinjauan pustaka}

Perpres 74/2013 menyatakan minuman beralkohol adalah minuman yang mengandung etil alkohol atau etanol $(\mathrm{C} 2 \mathrm{HSOH})$ yang diproses dari bahan hasil pertanian yang mengandung karbohidrat dengan cara fermentasi dan destilasi atau fermentasi tanpa destilasi. Kemudian, beleid tersebut juga memuat tentang defenisi minuman beralkohol tradisional yang pengertiannya adalah dibuat secara tradisional dan turun temurun yang dikemas secara sederhana dan pembuatannya dilakukan sewaktu-waktu, serta dipergunakan untuk kebutuhan adat istiadat atau upacara keagamaan.

\section{Pembahasan}

\section{A. pengertian minuman keras}

\section{Minuman}

keras (disingkat miras), minuman suling, atau spirit adalah minuman beralkohol yang mengandung etanol yang dihasilkan dari penyulingan (yaitu, berkonsentrasi lewat distilasi) etanol diproduksi dengan cara fermentasi bijibijian, buah, atau sayuran. Contoh minuman keras adalah arak, vodka, gin, baijiu, tequila, ru $\mathrm{m}$, wiski, brendi, dan soju.

Di Indonesia, definisi "minuman keras" dan "minuman beralkohol" tercampur aduk dan cenderung dianggap barang yang sama sehingga juga meliputi minuman fermentasi yang tidak disuling seperti bir, tuak, anggur, dan cider. Contoh dalam RUU Anti Miras yang telah dibuat sejak tahun 2013. Istilah "hard liquor" (juga berarti "minuman keras") digunakan di Amerika Utara dan India untuk membedakan minuman suling dari yang tidak disuling (jauh lebih rendah kadar alkoholnya).

B. Dampak minum minuman keras

- Penyakit hati Ketika dikonsumsi, alkohol akan terserap ke dalam aliran darah, kemudian terkumpul di hati untuk dipecah dan dinetralkan agar dapat dibuang dari tubuh. Hanya saja, kemampuan hati dalam memproses alkohol sangat terbatas. Jika alkohol yang diminum lebih banyak dari yang bisa diolah oleh hati, maka kadar alkohol dalam darah akan meningkat. Jika terus menerus terjadi, organ hati akan mengalami gangguan, mulai dari perlemakan hati, hepatitis, sirosis, hingga kanker hati.

- Penyakit jantung dan pembuluh darah

Akibat lainnya dari sering mabuk adalah gangguan detak jantung, peningkatan tekanan darah dan denyut jantung, pembesaran jantung, serta meningkatnya risiko terkena stroke dan penyakit jantung.

- Kanker

Semakin sering meminum minuman beralkohol, semakin besar pula risiko terkena kanker dan meninggal akibat penyakit tersebut. Selain kanker hati, jenis kanker lain yang juga dapat terjadi 
akibat sering mabuk adalah kanker mulut, kanker tenggorokan, kanker esofagus, kanker usus besar, bahkan kanker payudara.

- Gangguan otak dan saraf Terlalu banyak mengonsumsi alkohol juga dapat menyebabkan gangguan pada otak. Menurut penelitian, sering mabuk dapat membuat otak menyusut atau mengecil. Semakin banyak alkohol yang dikonsumsi, semakin besar pula penyusutannya. Selain itu, terlalu banyak minum alkohol juga dapat menurunkan kemampuan berpikir dan melemahkan daya ingat, serta membuat refleks dan koordinasi gerakan tubuh terganggu.

- Depresi

Sebagian orang menganggap bahwa mabuk dapat membantu mengatasi depresi. Namun, yang terjadi justru sebaliknya. Mengonsumsi minuman keras secara berlebihan justru dapat menyebabkan atau memperberat depresi. Penelitian menunjukkan bahwa orang yang sering mabuk memiliki risiko lebih tinggi untuk bunuh diri dan mengalami gangguan kecemasan.

Karena jika minum miras terlalu banyak, fungsi zat kimia otak yang mengatur mood akan terganggu, sehingga muncul gejala depresi.

- Kecanduan alkohol Sering mengonsumsi miras hingga mabuk juga dapat menyebabkan kecanduan. Meskipun menyadari bahaya alkohol, orang yang kecanduan akan terus-menerus mengonsumsi minuman beralkohol dan sulit untuk berhenti. Pada akhirnya, kebiasaan tersebut akan berdampak pada kesehatan maupun kehidupan sosialnya.

C. Dampak minuman keras terhadap kesehatan mental
Bila dikonsumsi berlebihan, minuman beralkohol dapat menimbulkan gangguan mental organik (GMO) yaitu gangguan dalam fungsi berpikir, merasakan, dan berperilaku.

Sehingga biasanya para pecandu alkohol menjadi rentan terserang berbagai penyakitkarena rendahnya daya tahanc kekebalan tubuh. Pengguna alkohol melampaui batas juga akan mengurangi kemampuan berpikir dan fungsi kerja organ tubuh lainnya.

Biasanya peminum alkohol juga akan menjadi lamban dalam berpikir atau bodoh, pelupa, dan mudah panik. Juga akan terjadi pembengkakan pembuluh darah yang bisa mengarah ke pecahnya pembuluh darah itu sendiri, sehingga berakibat kematian

D. Faktor remaja meminum minuman keras

Beberapa faktor resiko di dalam keluarga yang menyebabkan mengapa seorang remaja mengkonsumsi minuman beralkohol adalah:

- Kurangnya pengawasan atau komunikasi dengan orang tua

- Adanya permasalahan dalam keluarga

- Disiplin yang berubah-ubah atau justru terlalu berat

- Adanya anggota keluarga lain yang juga mengkonsumsi minuman beralkohol atau obat-obatan terlarang

Beberapa faktor resiko individual yang dapat menyebabkan seorang remaja mengkonsumsi minuman beralkohol adalah:

- Gangguan mengatur impuls

- Emosi tidak stabil 
- Memiliki keinginan untuk selalu menantang bahaya

- Tidak memiliki pengetahuan yang cukup akan bahaya mengkonsumsi minuman beralkohol

\section{Kesimpulan}

Banyak remaja di indonesia membudayakan minum minuman keras sebagai aktifitas biasa sedangkan bahaya minuman keras yang berdampak buruk bagi kesehatan ataupun bagi orang lain, penyakitnya pun tidak biasa hingga menyebabkan kematia. Dorongan untuk berhenti minum minuman keras untuk remaja yaitu niat dari diri sendiri dan juga dorongan dari orang lain. Yang bisa di lakukan yaitu mengadakan penyuluhan tentang bahayanya minuman keras. Kalau tidak di hentikan sejak dini akan berdampak buruk di hari tua nanti. 


\section{Daftar Pustaka}

Jurnal Pengaruh Ekspektansi pada Minuman Beralkohol terhadap Konsumsi Minuman Beralkohol

Wardah, F. R., \& Endang, R. S. (2013). Pengaruh Ekspektansi pada Minuman Beralkohol terhadap Konsumsi Minuman Beralkohol. Jurnal Psikologi Klinis dan Kesehatan Mental, 2(02).

\section{ALKOHOL DAN PENGARUHNYA TERHADAP KESEHATAN MENTAL}

Utina, S. S. (2012). Alkohol dan Pengaruhnya Terhadap Kesehatan Mental. Jurnal Health and Sport, 5(2).

PENGARUH PENGGUNAAN MINUMAN KERAS PADA KEHIDUPAN REMAJA DI DESA KALI KECAMATAN PINELENG KABUPATEN MINAHASA

Rori, P. L. P. (2016). Pengaruh penggunaan minuman keras pada kehidupan remaja di desa Kali kecamatan Pineleng kabupaten Minahasa. HOLISTIK, Journal Of Social and Culture.

SOSIALISASI BAHAYA MINUMAN KERAS BAGI REMAJA

Nurbiyati, T. (2014). Sosialisasi Bahaya Minuman Keras Bagi Remaja. Asian Journal of Innovation and Entrepreneurship, 3(03), 186-191. 